\title{
Survival of the Fittest: The Impact of the Minimum Wage on Firm Exit
}

\section{Citation}

Luca, Dara Lee, and Michael Luca. "Survival of the Fittest: The Impact of the Minimum Wage on Firm Exit." Harvard Business School Working Paper, No. 17-088, April 2017.

\section{Permanent link}

http://nrs.harvard.edu/urn-3:HUL.InstRepos:33111775

\section{Terms of Use}

This article was downloaded from Harvard University's DASH repository, and is made available under the terms and conditions applicable to Open Access Policy Articles, as set forth at http:// nrs.harvard.edu/urn-3:HUL.InstRepos:dash.current.terms-of-use\#OAP

\section{Share Your Story}

The Harvard community has made this article openly available.

Please share how this access benefits you. Submit a story.

\section{Accessibility}




\section{Survival of the Fittest: The Impact of the Minimum Wage on Firm Exit}

Dara Lee Luca Michael Luca

Working Paper 17-088 


\title{
Survival of the Fittest: The Impact of the Minimum Wage on Firm Exit
}

\author{
Dara Lee Luca \\ Mathematica Policy Research \\ Michael Luca \\ Harvard Business School
}

Working Paper 17-088 


\title{
Survival of the Fittest: \\ The Impact of the Minimum Wage on Firm Exit ${ }^{*}$
}

Dara Lee Luca $^{\dagger}$ and Michael Luca $\$$

April 2017

\begin{abstract}
We study the impact of the minimum wage on firm exit in the restaurant industry, exploiting recent changes in the minimum wage at the city level. The evidence suggests that higher minimum wages increase overall exit rates for restaurants. However, lower quality restaurants, which are already closer to the margin of exit, are disproportionately impacted by increases to the minimum wage. Our point estimates suggest that a one dollar increase in the minimum wage leads to a 14 percent increase in the likelihood of exit for a 3.5-star restaurant (which is the median rating), but has no discernible impact for a 5 -star restaurant (on a 1 to 5 star scale).
\end{abstract}

\footnotetext{
* We thank Susan Athey, Carl Bialik, Weijia Dai, Hilary Hoynes, Larry Katz, Hyunjin Kim, Kevin Lang, Luther Lowe, Andrei Shleifer, and seminar participants at the AEA conference for valuable feedback. We thank Stephanie Chan for providing excellent research assistance for this project. Data access, funding, and support were provided by Yelp as part of an economic research initiative with the company. Funding and the ability to publish were not tied to the results of this analysis. All remaining errors are our own.

† Mathematica Policy Research, DLeeLuca@mathematica-mpr.com

* Harvard Business School, mluca@hbs.edu
} 


\section{Introduction}

The minimum wage has recently re-entered the forefront of policy discourse as federal proposals range from leaving it as is, or increasing it to $\$ 10.10$ or even higher. Some proposals include raising the federal minimum to uncharted territory of $\$ 15$ per hour. ${ }^{1}$ While the federal minimum wage has remained stagnant since 2009, states - and more recently, cities - have increasingly set local minimum wages above the federal mandate of \$7.25. In the San Francisco Bay Area alone, there have been twenty-one local minimum wage changes over the past decade.

In this paper, we investigate the impact of the minimum wage on restaurant closures using data from the San Francisco Bay Area. We find suggestive evidence that an increase in the minimum wage leads to an overall increase in the rate of exit. However, this masks important heterogeneity. At any minimum wage level, lower quality restaurants, as proxied by their ratings on the review platform Yelp are more likely to exit. Moreover, lower quality restaurants are disproportionately affected by minimum wage increases. In other words, the impact of the minimum wage on exit is more pronounced among lower-rated restaurants.

The restaurant industry in the Bay Area makes a compelling setting to investigate the impact of the minimum wage on small businesses. First, the restaurant industry is the most intensive employer of minimum wage workers (U.S. Bureau of Labor Statistics, 2016b). Second, there is high turnover within the restaurant industry. In our sample - which covers restaurants in the Bay Area from 2008 through 2016 - roughly 5 percent of restaurants go out of business each year. Hence, the exit margin is economically meaningful. Additionally, there is no tip credit in

\footnotetext{
${ }^{1}$ While his exact stance on the minimum wage is not clear, President Trump has intimated that he would prefer to eliminate the federal minimum wage and let states determine their own minimum wages (http://www.politico.com/blogs/2016-presidential-debate-fact-check/2016/10/trump-kaine-minimum-wage-229149). Bernie Sanders proposed a $\$ 15$ federal minimum wage as part of his presidential campaign in 2016 (https://berniesanders.com/issues/a-living-wage/).
} 
California. Hence, tips do not count toward the official wage and wait staff are covered by the same minimum wage as other employees, so the minimum wage is more likely to be binding. Finally, there has been a substantial number of city-level minimum wage increases in the area since 2008, with a number of cities implementing minimum wages upwards of $\$ 12$.

Our analysis proceeds in three stages. First, we provide evidence that lower quality businesses are, on average, closer to the margin of exit and fail at higher rates than higher quality restaurants irrespective of the minimum wage level. A one-star increase in rating is associated with more than a 50\% decrease in the likelihood of going out of business. This qualitative relationship holds both with and without restaurant effects.

We then exploit the multiple city-level minimum wage changes in recent years across the Bay Area to implement a difference-in-differences design to investigate the effects of the minimum wage. We find suggestive evidence that a higher minimum wage leads to overall increases in restaurant exit rates - depending on the specification, we find that a $\$ 1$ increase in the minimum wage leads to approximately a 4 to 10 percent increase in the likelihood of exit, although the estimate is only statistically significant in certain specifications.

Next, we present robust evidence that the impact of the minimum wage varies with the rating of the business. Our point estimates suggest that a $\$ 1$ increase in the minimum wage leads to an approximate 14 percent increase in the likelihood of exit for the median 3.5-star restaurant but the impact falls to zero for five-star restaurants. These effects are robust to a number of different specifications, including controlling for time-varying county characteristics that may influence both minimum wage policies and restaurant demand, city-specific time trends to account for preexisting trends, as well as county-year fixed effects to control for spatial heterogeneity in exit trends. 
Our results contribute to the existing literature in several ways. First, our findings relate to a large literature seeking to estimate the impact of the minimum wage, most of which has focused on identifying employment effects. While some studies find no detrimental effects on employment (Card and Krueger 1994, 1998; Dube, Lester \& Reich, 2010), others show that higher minimum wage reduces employment, especially among low-skilled workers (see Neumark \& Wascher, 2007 for a review). However, even studies that identify negative impacts find fairly modest effects overall, suggesting that firms adjust to higher labor costs in other ways. For example, several studies have documented price increases as a response to the minimum wage hikes (Aaronson, 2001; Aaronson, French, \& MacDonald, 2008; Allegretto \& Reich, 2016). Horton (2017) find that firms reduce employment at the intensive margin rather than on the extensive margin, choosing to cut employees hours rather than counts. Draca et al. (2011) document lower profitability among firms for which the minimum wage may be more binding.

Our study contributes to the existing literature by examining one channel of adjustment to the minimum wage that has received relatively little attention - firms could exit the market altogether. We provide suggestive evidence that the minimum wage increases overall restaurant exit. This finding is consistent with Aaronson et al. (forthcoming), who use a border discontinuity approach to show that restaurant exit increases after the minimum wage increases.

However, our results reveal that the average treatment effect can be substantially different from the impact on sets of businesses that are predictably closer to the margin. While lower rated restaurants are driven to exit by increases to the minimum wage, higher rated restaurants tend to be more insulated from such shocks. This helps to shed light on the likely impact of minimum wage increases on existing businesses. . 
Our analysis also highlights how digital data can be used to better understand labor policy and the economy. Historically, datasets from the US Census Bureau and the Bureau of Labor Statistics (BLS) have formed the backbone of analyses looking to estimate the impact of the minimum wage in the US (e.g. Dube, Lester \& Reich, 2010, Aaronson et al., forthcoming). Other analyses consist mainly of researcher-administered surveys (e.g. Katz \& Krueger, 1992; Card \& Krueger, 1994).

While administrative datasets are critical to our understanding of the minimum wage and the economy more generally, the effects we identify in this paper would have been difficult to observe using standard datasets. The growth of online review platforms such as Yelp allows for unique insights into the economy. First, we can use each restaurant's rating as a proxy for its quality, , a measure that is not captured by conventional datasets. This lets us to evaluate whether the minimum wage differentially impacts lower quality businesses. Second, we are able to use exit data in close to real time, whereas BLS and Census data only become publicly available after a lag. This allows researchers and policymakers to more quickly understand the impacts of different economic policies. Third, we are able to observe granular data on businesses, whereas the public versions of the Census and BLS data are aggregated to coarser geographic levels, such as by county (depending on the variable the researcher is interested in). In principle, researchers can access restricted business-level data via an extensive application process, but the current waiting period for access even among approved applications is estimated to be two years. For example, a researcher trying to understand the impact of a policy change in 2017 would not be able to examine firm-level microdata from the Census until at least 2020. By using digital data, researchers can measure the impacts in close to real time. 
The rest of the paper proceeds as follows. We discuss the landscape of minimum wages across the United States in recent years in Section II. Section III discusses the data and empirical evidence, as well as graphical evidence. Section IV reports the main results, and Section V concludes.

\section{The Minimum Wage in Recent Years}

The current federal minimum wage of $\$ 7.25$ is binding for roughly 2.6 million hourly workers (U.S. Bureau of Labor Statistics, 2016a), with the restaurant industry having the highest percent of employees at the minimum (U.S. Bureau of Labor Statistics, 2016b). In addition to the $\$ 7.25$ federal minimum wage rate, 29 states and 41 cities have introduced higher than federal minimum wage. For example, San Francisco is set to increase its minimum wage to $\$ 15$ in July 2018 from its current wage of $\$ 12.25$.

We focus our analysis on the Bay Area, a region comprising of 101 cities surrounding the San Francisco Bay. The Bay Area is home to more than 7.5 million people, and includes the major cities and metropolitan areas of San Jose, San Francisco, and Oakland. Among the 41 cities and counties that have changed their minimum wage ordinances at the local level since 2012, 15 were in the Bay Area. ${ }^{2}$ We document 21 total local changes during our sample period from 2008 through 2016, with four additional cities set to increase their minimum beginning in 2017. Beyond the wide variation in minimum wage, focusing on a single region potentially allows us to better control for macroeconomic trends and attitudes towards labor standards.

\footnotetext{
${ }^{2}$ See http://laborcenter.berkeley.edu/minimum-wage-living-wage-resources/inventory-of-us-city-and-countyminimum-wage-ordinances/
} 
Figure 1 depicts the changes for the state of California and 11 cities in the state of California that have increased their minimum wage since $2008 .{ }^{3}$ In cities with separate minimum wages for large (usually defined as over 500 employees) and small companies, we use the minimum wage for small companies. This is because the majority of full-service and limitedservice restaurants have fewer than 500 employees (U.S. Census Bureau, 2014). At the state level, the minimum wage was set at $\$ 8$ in the beginning of the sample, increased to $\$ 9$ in 2014 , and then to $\$ 10$ in 2016.

\section{Data and Empirical Strategy}

\section{A. Restaurant Data}

Our underlying restaurant data are obtained from Yelp, as part of an ongoing economic research initiative done in collaboration with the company. Yelp was founded in 2004 in San Francisco and is now the dominant review platform in the US. On Yelp, users can leave text reviews and ratings (from 1 to 5) for individual businesses, ranging from dry cleaners to dentists. However, it is perhaps best known as a review platform for restaurants.

We start with the universe of all Yelp reviews for the Bay Area since 2008, and limit the dataset to only reviews for full-service and limited-service restaurants. Based on the review-level data, we form an unbalanced panel dataset at the restaurant-month level, where a restaurant enters the panel when it becomes active on Yelp (either by the owner registering the business, a reviewer registering the business, or receiving the first review), and leaves the panel after it has been marked as having been closed on Yelp.

\footnotetext{
${ }^{3}$ Four additional cities (San Leandro, Cupertino, Los Altos, San Mateo) are slated to increase their minimum wage above the state level in 2017.
} 
The indicator for restaurant exit is crowdsourced. On each restaurant's Yelp page, users have the option of updating the restaurant's business details, including tagging it as having closed or moved. Any suggested changes are then verified by Yelp moderators before being marked as such on the restaurant's profile page. In practice, timing of exit through Yelp may also be more accurate than official administrative data, which contains nontrivial reporting lags and errors. In the review data, we exclude filtered reviews, which are deemed by Yelp's algorithm as more likely to be fake or untrustworthy (Luca \& Zervas, 2016). The dataset contains basic information about the restaurant, including the type of cuisine (e.g., "New American", "Chinese"), the price category of the restaurant (denoted by dollar signs ranging from $\$$ to $\$ \$ \$$, with four dollar signs being the most expensive $)^{4}$, the exact location, and also time-varying characteristics such as the running average rating, the number of reviews, and exit status. ${ }^{5}$

Yelp coverage of restaurants is close to universal in the Bay Area. Comparing Yelp data to administrative data obtained for the city of San Francisco, ${ }^{6}$ the number of restaurants active at the end of 2016 is 6,087 and 5,808 based on the San Francisco administrative and Yelp data, respectively. Exit statistics generated from the two datasets are similar and consistent with previous research. For example, a common statistic that the restaurant industry focuses on is the rate of closure within one year of entry. Based on the administrative data, 19.8 percent of restaurants exit within one year of entry, whereas Yelp data indicates 20.9 percent. Other research on the restaurant industry has demonstrated similar numbers ranging from 23 percent in

\footnotetext{
${ }^{4}$ Price category is a crowd sourced element. Upon reviewing a restaurant, users are able to designate dollar signs based on the following criteria: $\$=$ under $\$ 10, \$ \$=11-30, \$ \$ \$=31-60, \$ \$ \$=$ over $\$ 61$.

${ }^{5}$ We constructed these variables such that they capture the measure at the end of the month, for example, the running average of the restaurant at the end of the month, or the displayed rating at the end of the month.

${ }^{6} \mathrm{SF}$ OpenData is the central clearinghouse for data published by the City and County of San Francisco, and includes a database of registered businesses that pay taxes, including their date of entry and exit. We restricted to the NAICS code of 722 (full-service restaurants and limited-service restaurants).
} 
Dallas, Texas (Cline Group, 2003) to around 26 percent in Columbus, Ohio (Parsa, Self, Njite, \& King, 2005).

We present two descriptive statistics of the data. The first set of statistics provides a snapshot of the restaurants' last appearance in the panel, i.e., at the end of 2016 or at the time of exit (Table 1 Panel A). There are 35,173 unique restaurants in our dataset, with a mean number of 184 reviews per restaurant and an average rating of $3.6^{7}$ Among the entire universe of restaurants, around 30 percent have closed. Restaurants remain in the panel for an average of 70 months ${ }^{8}$ and have an average price sign of 1.6 "dollar signs".

The second set of statistics shows a summary at the monthly panel level (Table 1 Panel B). A restaurant receives on average 2.5 new reviews each month with an average rating of 3.5. The likelihood of exit in any month is 0.4 percent.

\section{B. Graphical Evidence}

We first present graphical evidence of the relationship between a restaurant's operational status and its rating. Figure 2a depicts a snapshot of the overall distribution of restaurant ratings when last observed in the dataset. The modal rating is 3.5 , and ratings are generally more positive than negative; there are fewer than 5 percent of restaurants with ratings 2 and below, whereas 40 percent of restaurants have an average rating of 4 or above. Figure 2 b overlays the distribution by whether the restaurant has closed. The mass of ratings for closed restaurants is concentrated towards lower ratings relative to operating restaurants, suggesting that a restaurant's rating is correlated with closure

\footnotetext{
${ }^{7}$ While Yelp displays ratings rounded to the nearest 0.5 on their website, we use unrounded version in the analysis. (Whether we use the rounded or unrounded version of ratings does not affect the conclusions of our analysis.) ${ }^{8}$ Note that this statistic may not accurately represent average lifespan of a restaurant since when the restaurant becomes active on Yelp may not necessarily be the same as when the restaurant began operations.
} 
We further explore this by plotting the simple means of the monthly likelihood of exit by displayed rating (which is the average rating rounded to the nearest 0.5 ). Figure 3 depicts a clear negative relationship between the likelihood of exit and rating, again implying that restaurants with lower ratings are closer to the margin of exit.

Next we explore the cross-sectional relationship between the likelihood of exit and the minimum wage. Figure 4 plots the mean likelihood of exit by minimum wage, which shows a distinctly positive correlation. However, it is possible that larger or wealthier cities implement the minimum wage, and exit rates are systematically different (higher) in those cities as well. To investigate this, we obtain the residuals from regressing the likelihood of exit on city dummies, and plot the mean residuals against the minimum wage (Figure 5). While the slope is less pronounced, there still remains a positive relationship between the minimum wage and the likelihood of exit.

Figure 6 examines the likelihood of exit by restaurant rating and minimum wage. The figure synthesizes our empirical strategy and our main result: at any rating level, the likelihood of exit is higher when the minimum wage is higher. However, the increase in the likelihood of exit is greater for lower rated restaurants, and there does not appear to be any penalty for the highest rated restaurants. We confirm this finding using a regression framework in Section 4.

\section{Empirical Strategy}

The graphical evidence presented in Section 3.B suggests three things. First, restaurants with lower ratings are more likely to exit. Second, higher minimum wages are correlated with higher probabilities of exit. Third, the increase in the likelihood of exit is greater for lower rated restaurants. 
, We then use a difference-in-difference framework to empirically analyze the impact of the minimum wage on restaurant exit decisions, in which exploit the temporal and spatial variation in minimum wage increases at the city level across the Bay Area. The basic regression model, estimated as a linear probability model, is as follow:

$$
\operatorname{Exit}_{i j t}=\alpha_{i}+\phi_{t}^{\prime} \lambda+\beta M W_{j t}+X_{i j t}^{\prime} \delta+\mathrm{Z}_{j t}^{\prime} \rho+\varepsilon_{i j t}
$$

where $E{ } t_{i j t}$ is a binary variable denoting whether restaurant $i$ in city $j$ has exited by time $t . M W_{j t}$ is the minimum wage (measured in dollar amounts) in that city, $\alpha_{i}$ are restaurant fixed effects, $\phi_{t}^{\prime}$ is a vector of time controls, including year and quarter dummies to capture variation in macroeconomic conditions and seasonal variation in restaurant demand. $X^{\prime}{ }_{i j t}$ are time-varying restaurant measures, such as the number of ratings and lagged running average rating. ${ }^{9} \mathrm{Z}_{j t}^{\prime}$ includes a host of county-level time-varying characteristics that may influence both restaurant demand and minimum wage policies, including the percent of young workers between ages 15 to 24 , percent black, percent under the poverty line, the unemployment rate, and logged per capita income. $\varepsilon_{i j t}$ is the error term. In some specifications, we include city-specific time trends to account for preexisting trends in local exit rates. We also include county-year fixed effects in certain specifications to control for spatial heterogeneity in exit trends that are unrelated to minimum wage policies. The estimated impact of a $\$ 1$ increase in the minimum wage is then given by $\hat{\beta}$. Standard errors are clustered by city to allow for serial correlation within locale.

\footnotetext{
${ }^{9}$ Restaurant characteristics that are constant over time, such as the price category, location, type of cuisine, are controlled implicitly by restaurant fixed effects.
} 
We also enter the city-level minimum wage as the proportional increase over the state mandate, $\operatorname{Gap}_{j t}$. As an example, if the state minimum wage is $\$ 8$ and the city minimum wage is $\$ 9$, the Gap measure would be 12.5 . This measure reflects both increases in minimum wage within the city as well as relative to the state mandate.

We then estimate the heterogeneous effects of the minimum wage by including an interaction term of the minimum wage with the restaurant's rating. More specifically, our estimating equation becomes:

$$
\text { Exit }_{i j t}=\alpha_{i}+\phi^{\prime}{ }_{t} \lambda+\beta M W_{j t}+\gamma \text { Rating }_{i j t}+\theta M W_{j t} * \text { Rating }_{i j t}+X_{i j t}^{\prime} \delta+\mathrm{Z}_{j t}^{\prime} \rho+\varepsilon_{i j t}
$$

where $\hat{\theta}$ would provide an estimate of how the minimum wage affects exit by the restaurant's quality, as measured by its rating.

\section{Main Results}

As in our graphical evidence, we first examine the relationship between a restaurant's likelihood of exit and its Yelp rating (Table 2). Cross-sectionally, a one-star increase in rating is associated with a 0.09 percentage point decrease in the likelihood of exit in any given month (column 1), which is consistent with Figure 3. After controlling for restaurant fixed and calendar fixed effects, the coefficient increases to approximately -0.29 percentage point (Column 2 ). The relationship remains stable when we include time-varying county characteristics, city-specific time trends and county-year fixed effects (Columns 3-5). Our results imply a one-star increase in rating is associated with a decline in the likelihood of exit of around 70 percent. This is not necessarily a causal relationship - it is certainly possible that poor quality restaurants are both more likely to exit and receive worse ratings. It could also be that lower ratings directly contribute to restaurants exiting; as Luca (2011) shows, a one-star increase in Yelp rating leads 
to a 5 to 9 percent increase in restaurant revenue. Our objective is to test whether restaurants with lower ratings tend to be closer to the margin of exit.

We find suggestive evidence that higher minimum wage increases restaurant exit ( $\underline{\text { Table }}$ 3). Panel A reports the coefficients on the minimum wage entered as a dollar measure in the regression model, whereas Panel B reports those on the Gap variable as defined in Section III.C, which is a measure of how much the city minimum wage is above the state mandate. Crosssectionally, a one-dollar increase in the minimum wage is associated with a 0.09 percentage point increase in the probability of exit, which represents a 22 percent increase (Panel A Column 1). However, the estimate falls to 0.04 percentage points and loses statistical significance when we layer on restaurant and calendar fixed effects (Panel A Column 2). The estimate becomes even more imprecise when we include time-varying county characteristics that may influence both minimum wage policy and restaurant demand, city-specific time trends, and county-year fixed effects (Panel A Columns 3-5)

We find similar results when we examine the impact of the minimum wage as the percent increase over the state mandate, which may give a better measure of the "bite" of the minimum wage. Depending on the specification, our estimates suggest that a 10 -percent increase of the local minimum wage over the state mandate would increase the overall exit rate ranges from 0.016 to 0.04 percentage points, which corresponds to an increase in the likelihood of exit of 4 to 10 percent. While the estimates are generally more precise than in Panel A, they only reach statistical significance in certain specifications.

Overall impacts could mask underlying heterogeneous effects if the minimum wage differentially affects restaurants of varying quality. To examine this, we include the interaction effect between a restaurant's rating and the minimum wage, as specified in Equation (2). Table 4 
reports the main results of our paper: the minimum wage increases the likelihood of exit, but the impact falls for higher-rated restaurants. The estimates remain similar across the different specifications. Based on the estimates in Column (2), the results would suggest that the impact of a $\$ 1$ rise in the minimum wage would increase the likelihood of exit for the median restaurant on Yelp (i.e., a 3.5 star restaurant) by around 0.055 percentage points, which is approximately 14 percent. For a 5-star restaurant, this impacts falls to close to zero.

The results are consistent when we enter the minimum wage in the model as the percent above the state mandate (Table 5). A one-star increase in Yelp rating is associated with a 0.26 percentage point decline in the likelihood of exit for a restaurant in a city with the minimum wage equal to the state mandate, which is consistent with the results from Table 2. Further, the impact of the minimum wage varies by restaurant quality: a 10 percent increase in the minimum wage above the state mandate increases the likelihood of exit for a 3.5-star restaurant by 0.05 percentage points, translating into a 13.75 percent increase. The impact falls roughly by 0.09 percentage points for each star increase . The estimates are similar and statistically significant with city-specific time trends and county-year fixed effects. Finally, Figure 7 plots the predicted likelihood of exit by rating for different minimum wages from the specification in Table 4 Column 5, and echoes Figure 6. The figure shows that the predicted likelihood of exit is generally higher across ratings when the minimum wage is higher, but the impact, as well as the difference in impact across the three lines, shrinks as rating increases.

\section{Further Investigation}

\section{A. Are Results Driven by Restaurant Prices?}

If ratings are systematically correlated with prices - e.g., if cheap restaurants tend to receive low ratings, and expensive restaurants high ratings - then our results in Tables 4 and 5 
may be confounded. Further, it could be that more expensive restaurants already pay wages above the minimum, and hence are less affected by minimum wage hikes. Are the heterogeneous effects we observe driven by how expensive the restaurant is rather than its quality?

We empirically examine this question by replacing $M W_{j t} *$ Rating $_{i j t}$ in Equation 2 with the interaction term of the restaurant's price category (represented by dollar signs on Yelp) and the minimum wage $M W_{j t} *$ Price $_{i}$ (Table 6). The coefficient on the interaction term is small and statistically insignificant, suggesting that the effects of the minimum wage along the price

dimension are not significantly different (Column 1). When we include $M W_{j t} *$ Rating $g_{i j t}$ in the model as well, the coefficient on $M W_{j t} *$ Price $_{i}$ remains insignificant, whereas the coefficient on $M W_{j t} *$ Rating $_{i j t}$ are statistically significant and similar in magnitude to those in Table 5, providing evidence that the heterogeneous effects observed earlier are driven by quality rather than by the restaurant prices.

\section{B. Impact on Entry}

A natural follow-up question to our results on exit is the impact of the minimum wage on entry. Dates on restaurant entry only became regularly recorded by Yelp at the end of 2009, hence we restrict our entry analysis to the post- 2010 period. To examine entry, we generate a city-level panel dataset based on our restaurant-level dataset and estimate the analogous version of Equation (1) using the entry rate as the dependent variable, weighted by the number of restaurants on Yelp in that city.

$\underline{\text { Table } 7}$ reports the results of this exercise. First, we find similar overall impacts of the minimum wage on exit as our restaurant-level analysis (Columns 1-3). Next, we find that the entry rate in fact declines with minimum wage increases - depending on the specification, the 
entry rate declines by 0.025 to 0.045 percentage points from a base of 0.6 percent from a $\$ 1$ increase in the minimum wage, corresponding to an approximate 4 to 6 percent reduction. The number of restaurants per capita falls as expected, but the estimates are not statistically significant (Columns 7-9).

Our results suggest that higher minimum wages deter entry. Previous research on entry has produced mixed findings. Using a border discontinuity approach and data from Dun and Bradstreet Marketplace files, Rohlin (2011) finds that minimum wages hikes implemented between 2003 and 2006 discouraged firm entry - a \$1 increase in the minimum wage decreased the share of new establishments in an area relative to its comparison area by approximately 6 percent. Draca and Machin (2011) find some suggestive evidence that net entry rates decline after the imposition of a national minimum wage in the United Kingdom. In contrast, Aaronson et al. (forthcoming) finds that a 10 percent increase in the minimum wage increases the entry rate by roughly 14 percent from a mean of 8.7 percent using a similar border discontinuity approach and QCEW data.

\section{Impact on Survival}

In addition to the overall monthly likelihood of exit, we examine the effect of the minimum wage on restaurant time to exit. Since this relies on accurate coding of entry dates, we also restrict the analysis to after 2010. We estimate a survival model where the dependent variable is time to exit using a Weibull distribution (Table 8). The coefficients indicate that overall, the minimum wage increases the hazard rate, but the estimates are not statistically significant (Columns 1 and 3). However, when we interact the minimum wage with the restaurant's rating, we can see that the coefficient on the interaction term of minimum wage (or 
gap) with rating is negative and statistically significant, suggesting that the speed to exit is accelerated for poorly rated restaurants (Columns 2 and 4).

\section{Discussion}

This paper presents several new findings. First, we provide suggestive evidence that higher minimum wage increases overall exit rates among restaurants, where a $\$ 1$ increase in the minimum wage leads to approximately a 4 to 10 percent increase in the likelihood of exit, although statistical significance falls with the inclusion of time-varying county-level characteristics and city-specific time trends. This is qualitatively consistent but smaller than what Aaronson et al. (forthcoming) find; they show that a 10 percent raise in the minimum wage increases firm exit by approximately 24 percent from a base of 5.7 percent. Differences in sample and specifications may account for the differences between our study and theirs.

Next, we examine heterogeneous impacts of the minimum wage on restaurant exit by restaurant quality. The textbook competitive labor market model assumes identical workers and firms who therefore are equally likely to share in the minimum-wage generated employment and profit losses. However, models that depart from the standard competitive model to allow for heterogeneous workers and firms suggest that a minimum wage increase would cause the lowest productivity firms to exit the market (Albrecht \& Axell, 1984; Eckstein \& Wolpin, 1990; Flinn, 2006). We show that there is, in fact, considerable and predictable heterogeneity in the effects of the minimum wage, and that the impact on exit is concentrated among lower quality restaurants, which are already closer to the margin of exit. This suggests that the ability of firms to adjust to minimum wage changes could differ depending on firm quality. Finally, we provide evidence that higher minimum wages deter entry, and hastens the time to exit among poorly rated restaurants. 
Our findings suggest directions for future research. First, because most minimum wage changes in our sample are relatively new, our results should be considered short-term impacts. Second, while we find that the minimum wage reduces net entry slightly, it is unclear how employment would be affected given that the scale of entering or incumbent restaurants could change. ${ }^{10}$ Third, our results raise the possibility that higher rated restaurants may adjust to higher minimum wages through other channels, such as substituting toward higher productivity workers when faced with a minimum wage (Horton, 2017), especially if higher quality restaurants are able to assortatively match with more productive workers (Eeckhout \& Kircher, 2011; Mendes et al., 2010).

Our results also demonstrate the potential for digital exhaust from online platforms to complement standard data sources to provide unique insight in policy evaluations. Glaeser et al (forthcoming) hypothesize that data from online platforms might provide dependent variables that are more granular and closer to real time, as well as independent variables that provide insight into dimensions of markets that were previously unobservable. Our analysis provides a case study in this, showing how digital exhaust from Yelp can further our understanding of the impact of the minimum wage.

\footnotetext{
${ }^{10}$ The limited existing evidence on the interaction effect of firm dynamics and employment has been mixed. Anderson et al. (forthcoming) find the minimum wage increases exit (and entry) but do not find any impacts on employment. Draca and Machin (2011) find some evidence that minimum wages decreases net entry but no significant effects on employment.
} 


\section{References}

Aaronson, D. (2001). Price pass-through and the minimum wage. Review of Economics and statistics, 83(1), 158-169.

Aaronson, D., French, E., \& MacDonald, J. (2008). The minimum wage, restaurant prices, and labor market structure. Journal of Human Resources, 43(3), 688-720.

Aaronson, D., French, E., Sorkin, I., \& To, T. (forthcoming). Industry Dynamics and the Minimum Wage: A Putty-Clay Approach. International Economic Review.

Albrecht, J. W., \& Axell, B. (1984). An equilibrium model of search unemployment. Journal of Political Economy, 92(5), 824-840.

Allegretto, S. \& Reich, M. (2016). Are local minimum wages absorbed by price increases? Estimates from internet-based restaurant menus. IRLE Working Paper No. 124-15.

Belman, D. \& Wolfson, P. J. (2014). What Does the Minimum Wage Do?. Kalamazoo, MI: W.E. Upjohn Institute for Employment Research.

Card, D. \& Krueger, A. B. (1994) Minimum wages and employment: a case study of the fastfood industry in New Jersey and Pennsylvania. American Economic Review, 84(4), 772-793.

Card, D. and A. B. Krueger. "Minimum Wages And Employment: A Case Study Of The FastFood Industry In New Jersey And Pennsylvania: Reply," American Economic Review, 2000, v90(5,Dec), 1397-1420.

Cline Research Group. (2003). Restaurant Failure Rate Study. Retrieved from https://www.restaurantowner.com/public/263.cfm

Draca, M., Machin, S., \& Van Reenen, J. (2011). Minimum wages and firm profitability. American Economic Journal: Applied Economics, 3(1), 129-151.

Dube, A. T., Lester, W., \& Reich, M. (2010). Minimum wage effects across state borders: Estimates using contiguous counties. The Review of Economics and Statistics, 92(4), 945964.

Eckstein, Z., \& Wolpin, K. I. (1990). Estimating a market equilibrium search model from panel data on individuals. Econometrica: Journal of the Econometric Society, 783-808.Eeckhoust, J. \& Kircher, P. (2011). Identifying sorting-in theory. Review of Economic Studies, 78(3), 872-906.

Eeckhout, J., \& Kircher, P. (2011). Identifying sorting-in theory. The Review of Economic Studies, rdq034.

Flinn, C. J. (2006). Minimum wage effects on labor market outcomes under search, matching, and endogenous contact rates. Econometrica, 74(4), 1013-1062. 
Glaeser, E., Kominers, S., Luca, M., \& Naik, N. (forthcoming) Big data and big cities: The promises and limitations of improved measures of urban life

Horton, J. J. (2017). Price floors and employer preferences: Evidence from a minimum wage experiment. Working paper.

Katz, L. F., \& Krueger, A. B. (1992). The effect of the minimum wage on the fast food industry. Industrial and Labor Relations Review, 46(1), 6-21.

Luca, M. (2011). Reviews, reputation, and revenue: The case of Yelp.com. Harvard Business School NOM Unit Working Paper 12-016, 1-40.

Luca, M., \& Zervas, G. (2016). Fake it till you make it: reputation, competition, and Yelp review fraud. Management Science, 62(12), 3412-3427.

Mendes, R., van den Berg, G. J., \& Lindeboom, M. (2010). An empirical assessment of assortative matching in the labor market. Labour Economics, 17(6), 919-929.

Neumark, D., \& Wascher, W. (2000). Minimum wages and employment: A case study of the fast-food industry in New Jersey and Pennsylvania: Comment. The American Economic Review, 90(5), 1362-1396

Neumark, D. \& Wascher, W. (2007) Minimum wage and employment In W.K. Viscusi (Ed.), Foundations and Trends in Microeconomics Vol 3 No. 1-2 (pp 1-182). Boston, MA: Now Publishers.

Parsa, H. G., Self, J. T., Njite D., \& King, T. (2005) Why restaurants fail. Cornell Hotel and Restaurant Administration Quarterly, 46(3), 304-322.

U.S. Bureau of Labor Statistics. (2016a). Characteristics of minimum wage workers, 2015. BLS Report 1061. Retrieved from https://www.bls.gov/opub/reports/minimumwage/2015/pdf/home.pdf

U.S. Bureau of Labor Statistics. (2016b). Occupational employment and wages, May 2015. Retrieved from https://www.bls.gov/oes/current/oes350000.htm

U.S. Census Bureau. (2014). Data by enterprise employment size. Retrieved from https://www.census.gov/data/tables/2014/econ/susb/2014-susb-annual.html 
Figure 1. Minimum wage increases in the San Francisco Bay Area
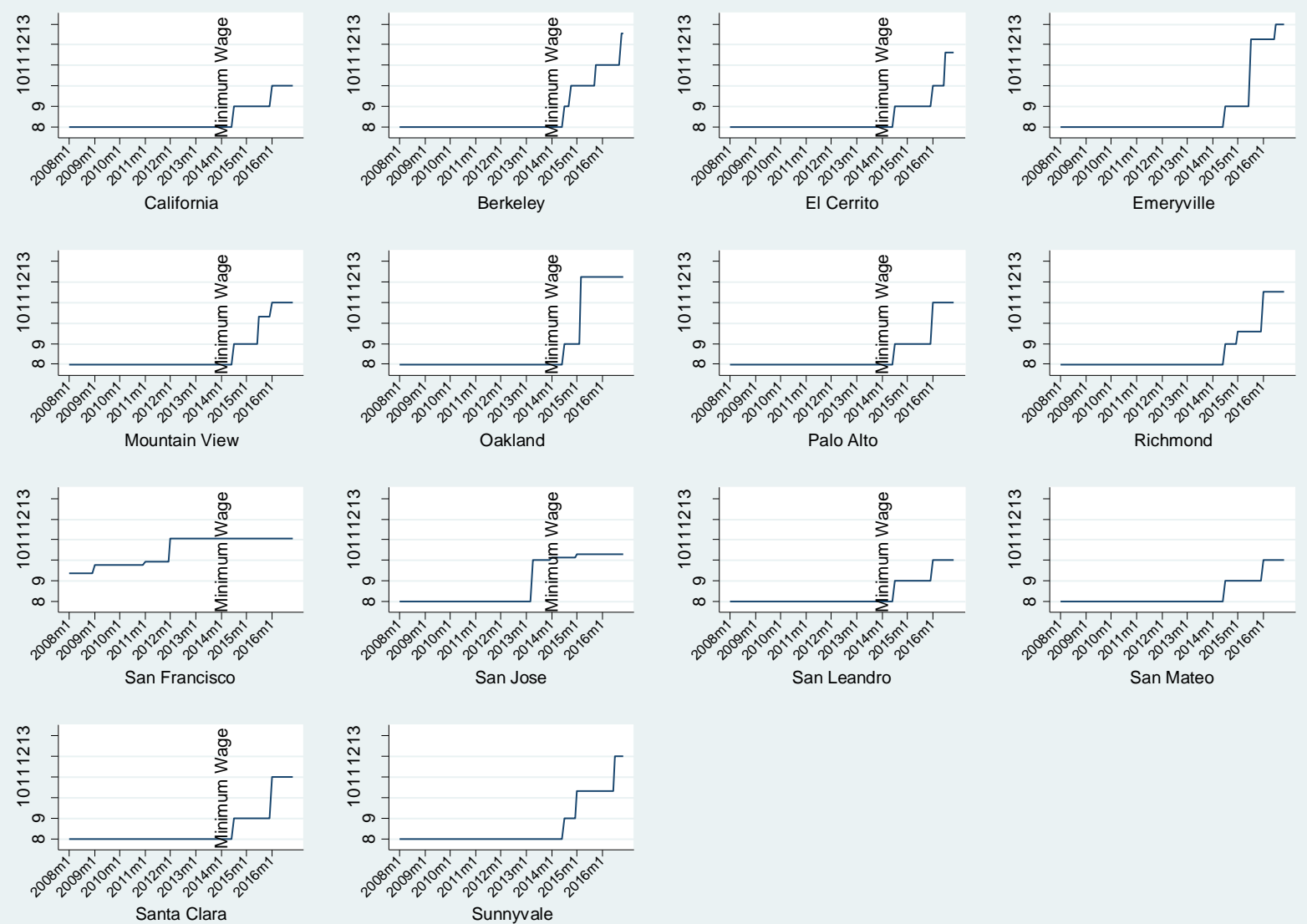
Figure 2a. Overall distribution of Yelp ratings

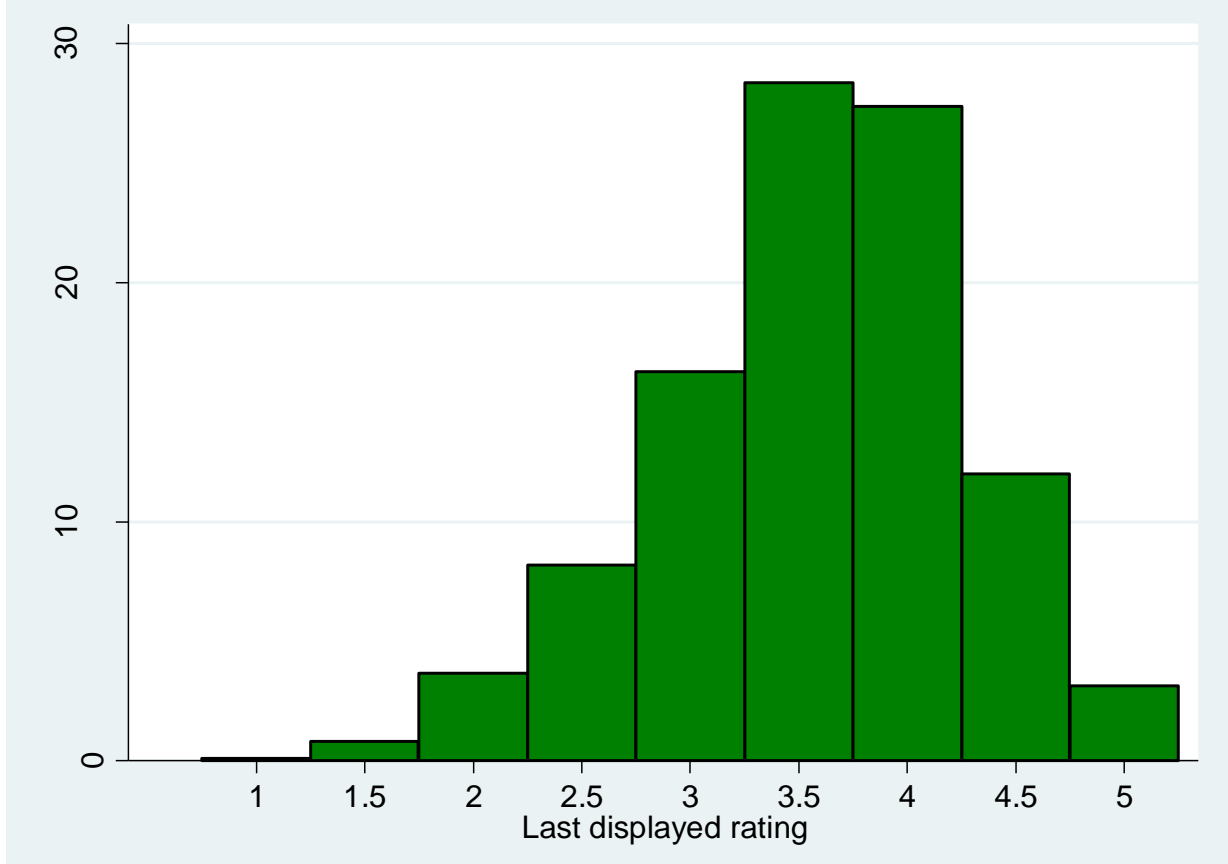

Figure 2b. Closed restaurants have lower ratings

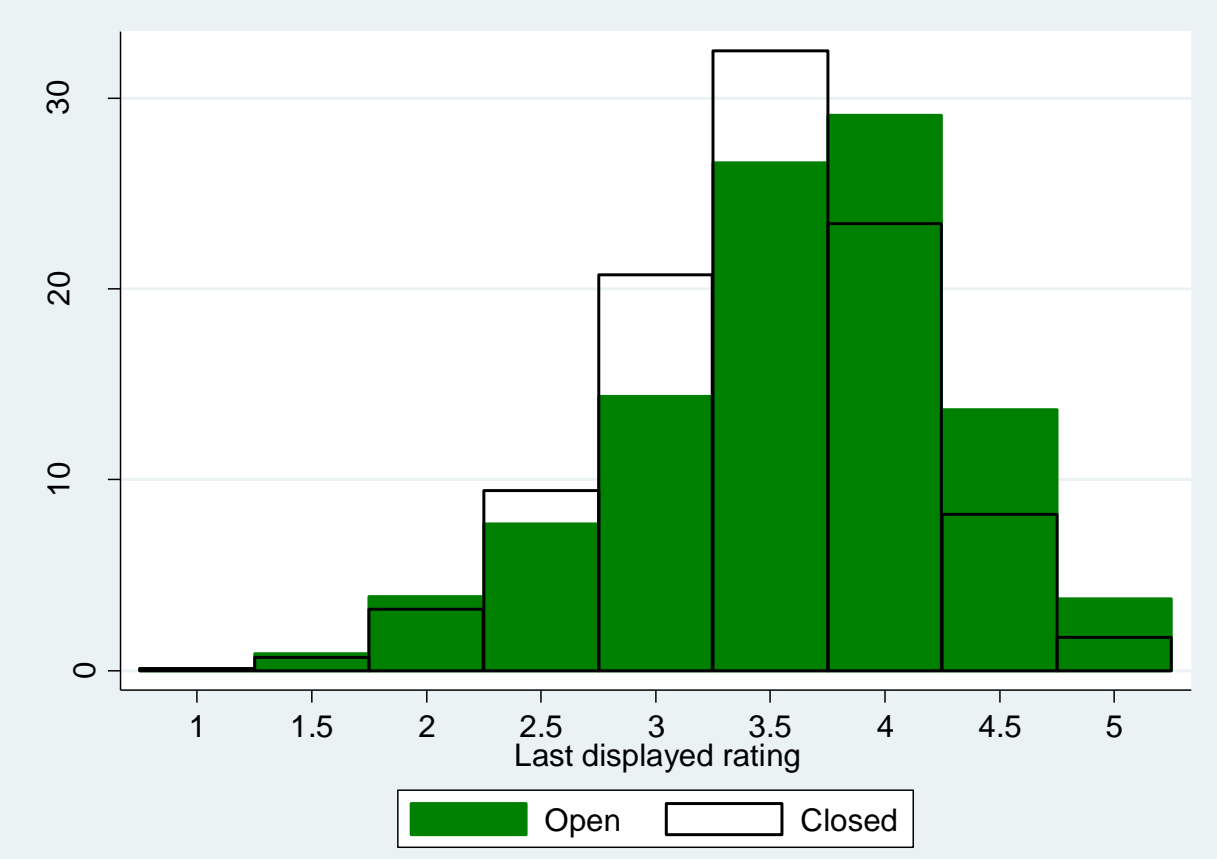


Figure 3. Lower rated restaurants are more likely to exit

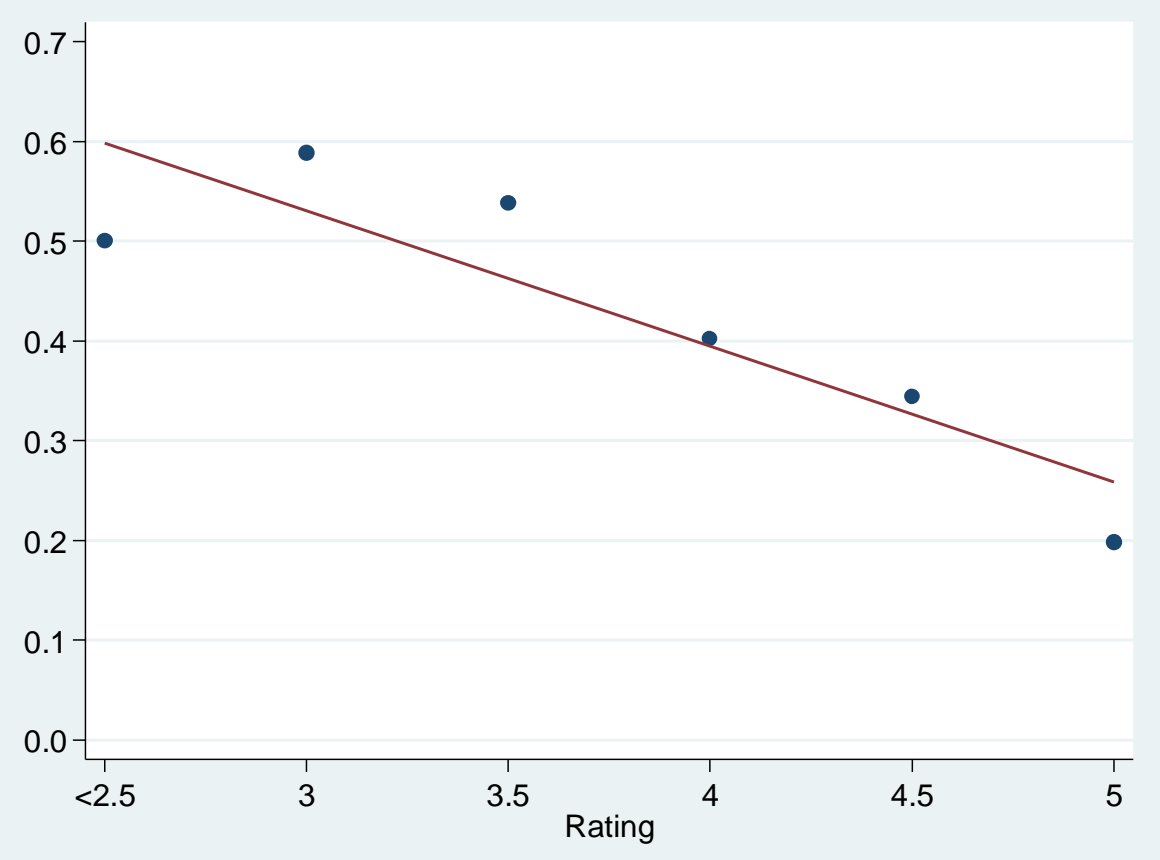

Note: This figure plots the monthly likelihood of exit at each Yelp rating.

\section{Figure 4. Minimum wage and likelihood of exit}

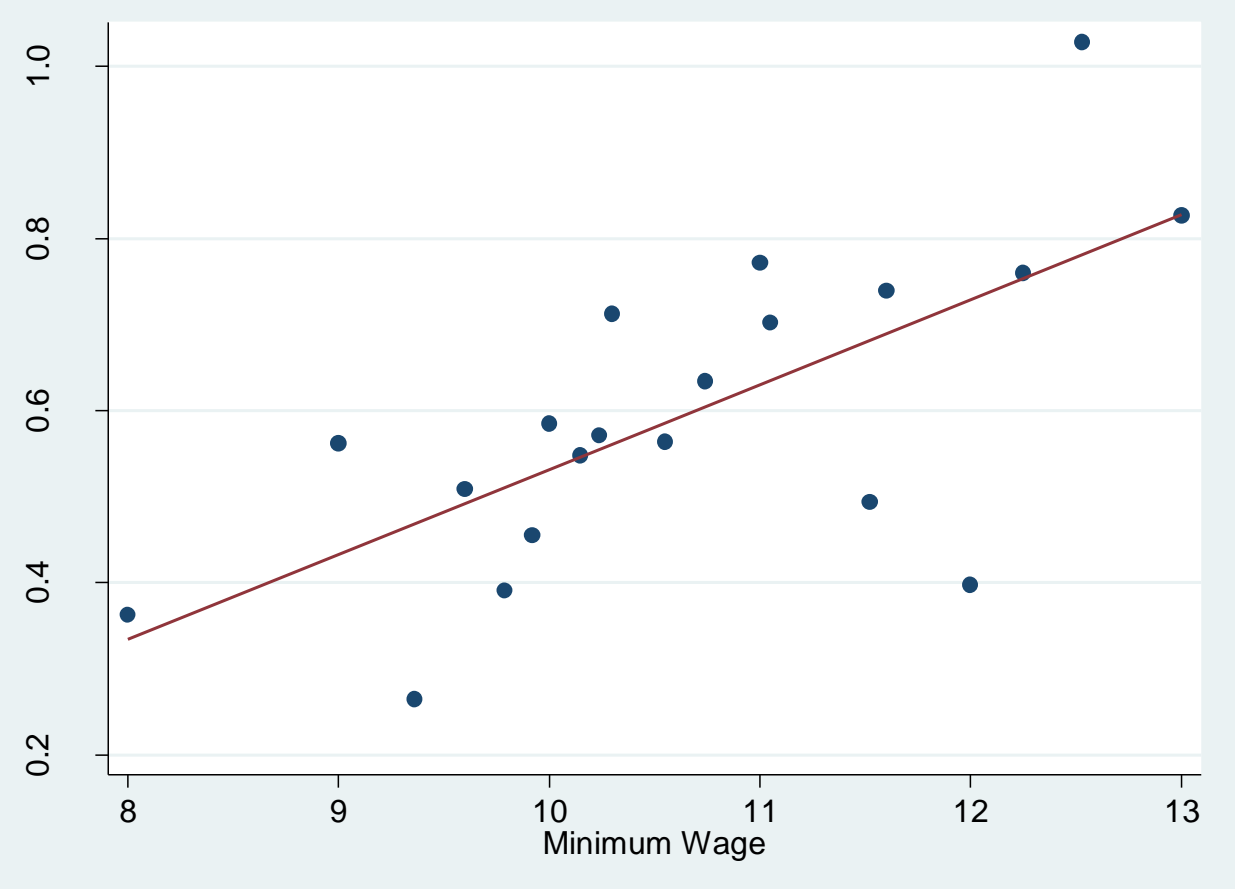

Note: This figure plots the simple means of the likelihood of exit at each minimum wage. 
Figure 5. Minimum wage and likelihood of exit (within city)

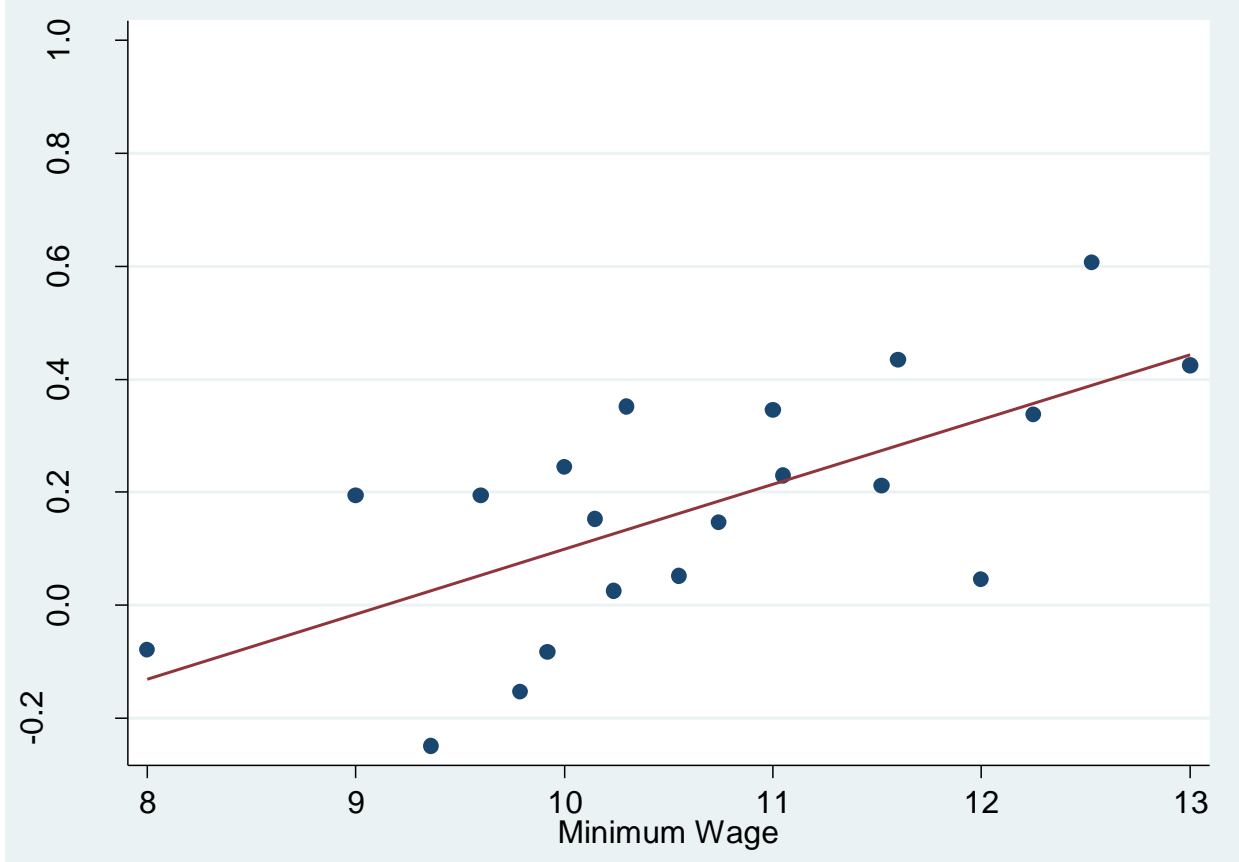

Note: This figure plots the simple means of the residuals of regressing the likelihood of exit on city fixed effects at each minimum wage.

Figure 6. Minimum wage increases exit, but more so for worse restaurants

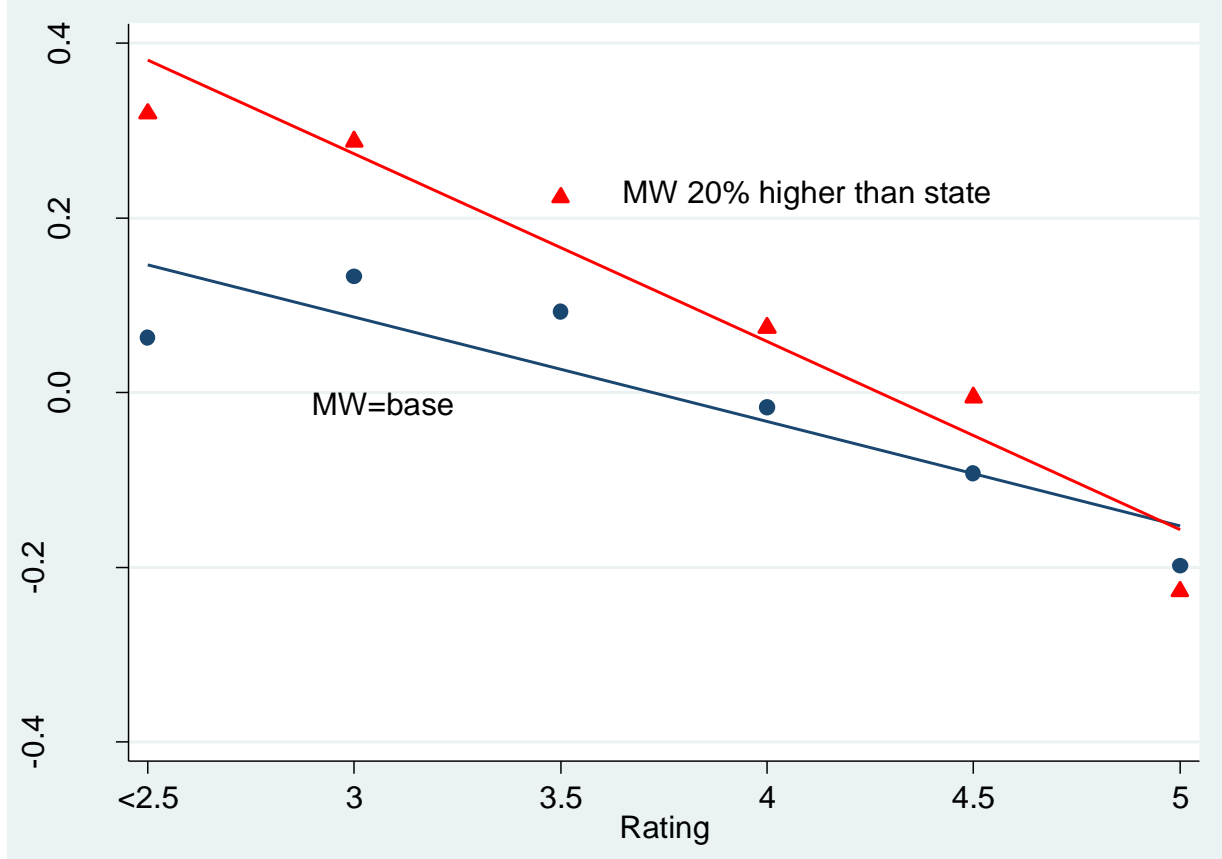


Figure 7. Predicted likelihoods of exit by minimum wage and rating

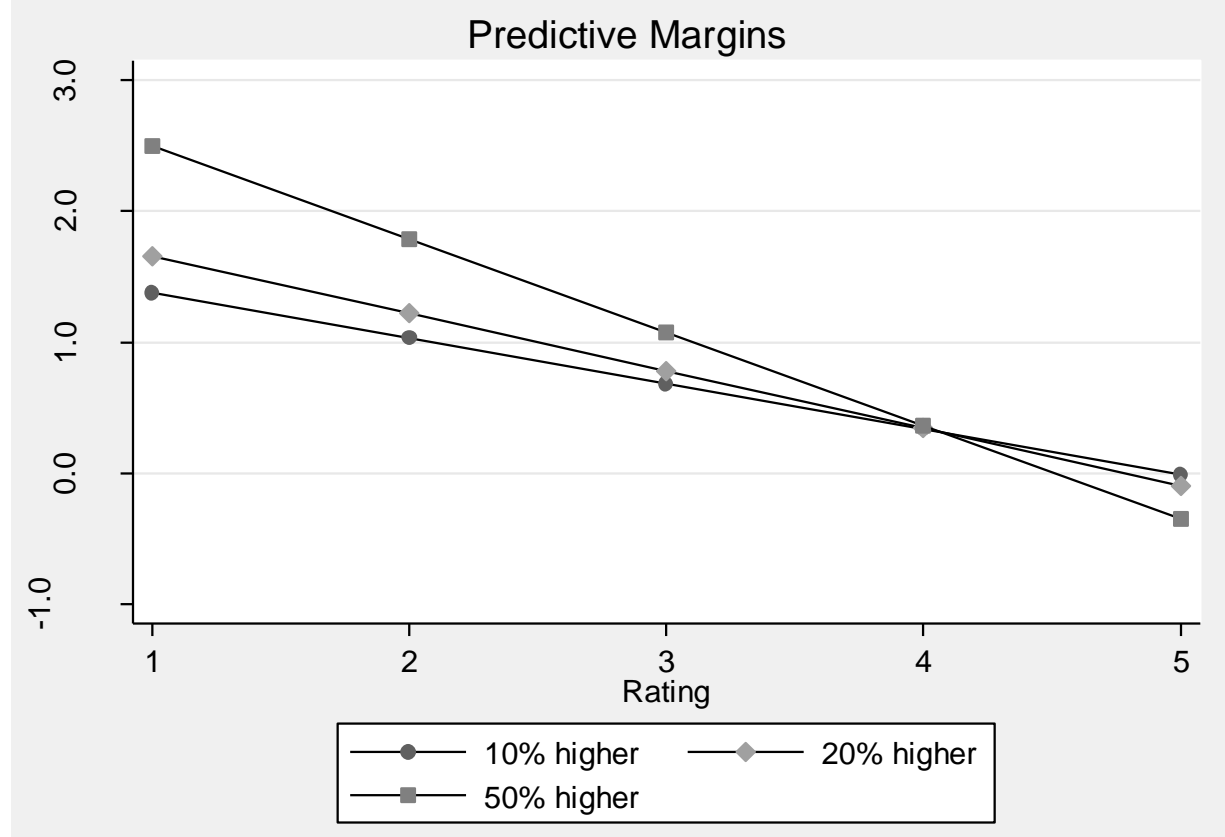

Note: This figure plots the predicted likelihood of exit by rating and the percent increase of local minimum wage above the state mandate based on the estimates from Table 4 Column 5. 
Table 1. Descriptive statistics

Number of restaurants $\quad 35,173$

Number of ratings $\quad 2,392,766$

Panel A: Summary statistics at the restaurant level (at time of last appearance in panel)

\begin{tabular}{|l|l|l|l|l|l|}
\hline & Mean & $\begin{array}{l}\text { Std } \\
\text { Dev }\end{array}$ & Min & Max & Obs. \\
\hline Total number of ratings & 184.4 & 327.1 & 10 & 9781 & 35,173 \\
Rating & 3.564 & 0.691 & 1 & 5 & 35,173 \\
Closed & 0.301 & 0.459 & 0 & 1 & 35,173 \\
Price category & 1.588 & 0.603 & 1 & 4 & 35,173 \\
Age of restaurants (months) & 67.73 & 36.52 & 1 & 107 & 35,173 \\
Minimum wage (\$) & 10.49 & 1.534 & 8 & 13 & 35,173 \\
$\begin{array}{l}\text { Percent higher than state } \\
\text { mw (\%) }\end{array}$ & 9.839 & 12.84 & 0 & 36 & 35,173 \\
\hline
\end{tabular}

Panel B: Summary statistics at the restaurant-month level

\begin{tabular}{|l|l|l|l|l|l|}
\hline Variable & Mean & $\begin{array}{l}\text { Std } \\
\text { Dev }\end{array}$ & Min & Max & Obs. \\
\hline Incoming ratings & 3.535 & 1.105 & 1 & 5 & $1,430,061$ \\
Number of incoming ratings & 2.454 & 4.790 & 0 & 690 & $2,383,558$ \\
Average running rating & 3.570 & 0.707 & 1 & 5 & $2,376,580$ \\
Exited (\%) & 0.464 & 6.792 & 0 & 100 & $2,392,766$ \\
Minimum wage (\$) & 9.033 & 1.291 & 8 & 13 & $2,392,766$ \\
$\begin{array}{l}\text { Percent higher than state } \\
\text { mw (\%) }\end{array}$ & 7.346 & 11.77 & 0 & 36.1 & $2,392,766$ \\
\hline
\end{tabular}


Table 2. Are lower rated restaurants more likely to exit?

\begin{tabular}{|c|c|c|c|c|c|}
\hline & \multicolumn{5}{|c|}{$\begin{array}{l}\text { Likelihood of Exit } \\
\qquad \text { (Mean = 0.4\%) }\end{array}$} \\
\hline & (1) & $(2)$ & (3) & (4) & $(5)$ \\
\hline Rating & $\begin{array}{c}-0.0938^{* * *} \\
(0.0116)\end{array}$ & $\begin{array}{c}-0.2893^{\star * *} \\
(0.0277)\end{array}$ & $\begin{array}{c}-0.2910^{\star * *} \\
(0.0287)\end{array}$ & $\begin{array}{c}-0.2935^{\star * *} \\
(0.0280)\end{array}$ & $\begin{array}{c}-0.2917^{* * *} \\
(0.0290)\end{array}$ \\
\hline Restaurant FE & & $x$ & $x$ & $x$ & $x$ \\
\hline Calendar FE & & $x$ & $x$ & $x$ & $x$ \\
\hline $\begin{array}{l}\text { Time-varying county } \\
\text { characteristics }\end{array}$ & & & $x$ & $x$ & $x$ \\
\hline City-specific time trend & & & & $x$ & \\
\hline County-year FE & & & & & $x$ \\
\hline
\end{tabular}

Standard errors are clustered at the city level

Number of observations $=2,392,766$

Calendar fixed effects $=$ dummies for season and year

Table 3. Overall minimum wage effects on restaurant exit

\begin{tabular}{|c|c|c|c|c|c|}
\hline & \multicolumn{5}{|c|}{$\begin{array}{l}\text { Likelihood of Exit } \\
\qquad(\text { Mean }=0.4 \%) \\
\end{array}$} \\
\hline & (1) & (2) & (3) & $(4)$ & (5) \\
\hline \multirow[t]{2}{*}{ Panel A: Minimum Wage } & $0.0929^{* \star *}$ & 0.0444 & 0.0174 & -0.0132 & 0.0263 \\
\hline & $(0.0079)$ & $(0.0284)$ & $(0.0197)$ & $(0.0134)$ & $(0.0181)$ \\
\hline \multirow[t]{2}{*}{ Panel B: Gap } & $0.0062^{\star \star *}$ & $0.0045^{*}$ & 0.0026 & 0.0016 & $0.0040 * *$ \\
\hline & $(0.0006)$ & $(0.0024)$ & $(0.0019)$ & $(0.0017)$ & $(0.0018)$ \\
\hline Restaurant FE & & $x$ & $x$ & $x$ & $\mathbf{x}$ \\
\hline Calendar FE & & $x$ & $x$ & $x$ & $x$ \\
\hline $\begin{array}{l}\text { Time-varying county } \\
\text { characteristics }\end{array}$ & & & $x$ & $x$ & $x$ \\
\hline City-specific time trend & & & & $x$ & \\
\hline County-year FE & & & & & $x$ \\
\hline
\end{tabular}

Standard errors are clustered at the city level

Gap is a measure of the proportional increase of the city minimum wage over the state mandate Number of observations $=2,392,766$

Calendar fixed effects $=$ dummies for season and year 
Table 4. Heterogeneous effects of the minimum wage as a dollar measure

\begin{tabular}{|c|c|c|c|c|c|}
\hline & \multicolumn{5}{|c|}{$\begin{array}{l}\text { Likelihood of Exit (\%) } \\
\qquad(\text { Mean }=0.4 \%)\end{array}$} \\
\hline & (1) & (2) & (3) & $(4)$ & (5) \\
\hline Minimum wage & $\begin{array}{l}0.1639^{* \star *} \\
(0.0208)\end{array}$ & $\begin{array}{c}0.2336^{\star * *} \\
(0.0786)\end{array}$ & $\begin{array}{c}0.2047^{* * *} \\
(0.0730)\end{array}$ & $\begin{array}{l}0.1746^{* *} \\
(0.0696)\end{array}$ & $\begin{array}{l}0.2148^{* * *} \\
(0.0732)\end{array}$ \\
\hline Rating & $\begin{array}{c}0.0653 \\
(0.0547)\end{array}$ & $\begin{array}{c}0.1598 \\
(0.1341)\end{array}$ & $\begin{array}{c}0.1521 \\
(0.1387)\end{array}$ & $\begin{array}{c}0.1514 \\
(0.1406)\end{array}$ & $\begin{array}{c}0.1526 \\
(0.1403)\end{array}$ \\
\hline Minimum Wage * Rating & $\begin{array}{c}-0.0190 * * * \\
(0.0064)\end{array}$ & $\begin{array}{c}-0.0527^{\star \star \star} \\
(0.0165)\end{array}$ & $\begin{array}{c}-0.0520^{* * *} \\
(0.0171)\end{array}$ & $\begin{array}{c}-0.0522^{\star * *} \\
(0.0172)\end{array}$ & $\begin{array}{l}-0.0521^{* * *} \\
(0.0174)\end{array}$ \\
\hline Restaurant FE & & $x$ & $x$ & $x$ & $x$ \\
\hline Calendar FE & & $x$ & $x$ & $x$ & $x$ \\
\hline $\begin{array}{l}\text { Time-varying county } \\
\text { characteristics }\end{array}$ & & & $x$ & $x$ & $x$ \\
\hline City-specific time trend & & & & $x$ & \\
\hline County-year FE & & & & & $x$ \\
\hline
\end{tabular}

Standard errors are clustered at the city level

Number of observations $=2,370,963$

Calendar fixed effects $=$ dummies for season and year

Table 5. Heterogeneous effects of the minimum wage measured as the proportional increase above the state mandate

\begin{tabular}{|c|c|c|c|c|c|}
\hline & \multicolumn{5}{|c|}{$\begin{array}{l}\text { Likelihood of Exit (\%) } \\
\qquad(\text { Mean }=0.4 \%)\end{array}$} \\
\hline & (1) & (2) & (3) & (4) & (5) \\
\hline Gap & $\begin{array}{c}0.0170^{* * *} \\
(0.0016)\end{array}$ & $\begin{array}{c}0.0371^{* * *} \\
(0.0096)\end{array}$ & $\begin{array}{c}0.0338^{* * *} \\
(0.0084)\end{array}$ & $\begin{array}{c}0.0325^{* * *} \\
(0.0081)\end{array}$ & $\begin{array}{c}0.0349^{* * *} \\
(0.0082)\end{array}$ \\
\hline Rating & $\begin{array}{c}-0.0831^{* * *} \\
(0.0101)\end{array}$ & $\begin{array}{c}-0.2557^{* * *} \\
(0.0218)\end{array}$ & $\begin{array}{l}-0.2589^{* * *} \\
(0.0208)\end{array}$ & $\begin{array}{c}-0.2615^{\star * *} \\
(0.0207)\end{array}$ & $\begin{array}{c}-0.2597^{* * *} \\
(0.0206)\end{array}$ \\
\hline Gap * Rating & $\begin{array}{c}-0.0029^{* * *} \\
(0.0004)\end{array}$ & $\begin{array}{l}-0.0091^{* * *} \\
(0.0021)\end{array}$ & $\begin{array}{l}-0.0087^{* * *} \\
(0.0019)\end{array}$ & $\begin{array}{l}-0.0086^{\star * *} \\
(0.0019)\end{array}$ & $\begin{array}{c}-0.0086^{* * *} \\
(0.0019)\end{array}$ \\
\hline Restaurant FE & & $x$ & $x$ & $x$ & $\mathrm{x}$ \\
\hline $\begin{array}{l}\text { Calendar FE } \\
\text { Time-varying county }\end{array}$ & & $x$ & $x$ & $\mathrm{x}$ & $\mathrm{x}$ \\
\hline $\begin{array}{l}\text { characteristics } \\
\text { City-specific time trend }\end{array}$ & & & $x$ & $\begin{array}{l}x \\
x\end{array}$ & $x$ \\
\hline County-year FE & & & & & $\mathrm{x}$ \\
\hline
\end{tabular}


Table 6. Are results driven by restaurant prices?

\begin{tabular}{|c|c|c|c|c|}
\hline & \multicolumn{4}{|c|}{$\begin{array}{l}\text { Likelihood of Exit (\%) } \\
\qquad .4\end{array}$} \\
\hline & (1) & (2) & (3) & (4) \\
\hline \multicolumn{5}{|l|}{ Panel A } \\
\hline$\overline{\text { Minimum Wage }}$ & $\begin{array}{c}0.0125 \\
(0.0300)\end{array}$ & $\begin{array}{l}0.1921^{* *} \\
(0.0796)\end{array}$ & $\begin{array}{l}0.1654^{* *} \\
(0.0758)\end{array}$ & $\begin{array}{l}0.2029^{* *} \\
(0.0803)\end{array}$ \\
\hline Minimum Wage * Price & $\begin{array}{c}0.0019 \\
(0.0102)\end{array}$ & $\begin{array}{c}0.0059 \\
(0.0106)\end{array}$ & $\begin{array}{c}0.0035 \\
(0.0103)\end{array}$ & $\begin{array}{l}0.0054 \\
(0.0107)\end{array}$ \\
\hline Rating & & $\begin{array}{c}0.1464 \\
(0.1424)\end{array}$ & $\begin{array}{c}0.1452 \\
(0.1441)\end{array}$ & $\begin{array}{l}0.1479 \\
(0.1435)\end{array}$ \\
\hline Minimum Wage * Rating & & $\begin{array}{l}-0.0516^{* * *} \\
(0.0177)\end{array}$ & $\begin{array}{l}-0.0518^{* * *} \\
(0.0178)\end{array}$ & $\begin{array}{l}-0.0519^{* * *} \\
(0.0178)\end{array}$ \\
\hline \multicolumn{5}{|l|}{ Panel B } \\
\hline Gap & $\begin{array}{c}0.0019 \\
(0.0028)\end{array}$ & $\begin{array}{l}0.0339^{* * *} \\
(0.0080)\end{array}$ & $\begin{array}{l}0.0330^{* * *} \\
(0.0075)\end{array}$ & $\begin{array}{l}0.0352^{* * *} \\
(0.0076)\end{array}$ \\
\hline Gap * Price & $\begin{array}{l}-0.0002 \\
(0.0013)\end{array}$ & $\begin{array}{c}0.0002 \\
(0.0014)\end{array}$ & $\begin{array}{l}-0.0001 \\
(0.0013)\end{array}$ & $\begin{array}{l}0.0000 \\
(0.0013)\end{array}$ \\
\hline Rating & & $\begin{array}{l}-0.2607^{\star \star *} \\
(0.0211)\end{array}$ & $\begin{array}{c}-0.2633^{\star \star *} \\
(0.0210)\end{array}$ & $\begin{array}{l}-0.2616^{* * \star} \\
(0.0210)\end{array}$ \\
\hline Gap * Rating & & $\begin{array}{c}-0.0089^{\star \star *} \\
(0.0019)\end{array}$ & $\begin{array}{c}-0.0088^{\star \star \star} \\
(0.0018)\end{array}$ & $\begin{array}{l}-0.0088^{\star \star *} \\
(0.0019)\end{array}$ \\
\hline Restaurant FE & $x$ & $x$ & $x$ & $x$ \\
\hline Calendar FE & $x$ & $x$ & $x$ & $x$ \\
\hline Time-varying county characteristics & $x$ & $x$ & $x$ & $x$ \\
\hline City-specific time trend & $x$ & & $x$ & \\
\hline County-year FE & & & & $x$ \\
\hline
\end{tabular}

Standard errors are clustered at the city level

Price indicates the price category of the restaurant, which ranges from 1 to 4

Gap is a measure of the proportional increase of the city minimum wage over the state mandate

Number of observations $=2,370,963$

Calendar fixed effects $=$ dummies for season and year 
Table 7. Minimum wage effects on exit, entry, and number of restaurants

\begin{tabular}{|c|c|c|c|c|c|c|c|c|c|}
\hline & \multicolumn{3}{|c|}{$\begin{array}{l}\text { Exit rate }(\%) \\
(\text { Mean }=0.4)\end{array}$} & \multicolumn{3}{|c|}{$\begin{array}{l}\text { Entry rate }(\%) \\
(\text { Mean }=0.6)\end{array}$} & \multicolumn{3}{|c|}{$\begin{array}{l}\text { Restaurants per } 10,000 \text { pop } \\
(\text { Mean }=45.3)\end{array}$} \\
\hline & (1) & (2) & (3) & (4) & (5) & (6) & (7) & (8) & (9) \\
\hline Minimum Wage & $\begin{array}{c}0.0038 \\
(0.0116)\end{array}$ & $\begin{array}{l}-0.0030 \\
(0.0126)\end{array}$ & $\begin{array}{c}0.0185 \\
(0.0138)\end{array}$ & $\begin{array}{l}-0.0425^{\star \star \star} \\
(0.0139)\end{array}$ & $\begin{array}{l}-0.0251^{*} \\
(0.0146)\end{array}$ & $\begin{array}{l}-0.0449^{\star *} \\
(0.0193)\end{array}$ & $\begin{array}{l}-0.1989 \\
(0.1478)\end{array}$ & $\begin{array}{l}-0.1149 \\
(0.1187)\end{array}$ & $\begin{array}{l}-0.1470 \\
(0.1534)\end{array}$ \\
\hline Gap & $\begin{array}{l}0.0018^{*} \\
(0.0011)\end{array}$ & $\begin{array}{c}0.0018 \\
(0.0012)\end{array}$ & $\begin{array}{c}0.0037^{* * *} \\
(0.0013)\end{array}$ & $\begin{array}{l}-0.0035^{\star \star \star} \\
(0.0010)\end{array}$ & $\begin{array}{l}-0.0026^{\star * *} \\
(0.0009)\end{array}$ & $\begin{array}{l}-0.0041^{\star * *} \\
(0.0015)\end{array}$ & $\begin{array}{l}-0.0102 \\
(0.0098)\end{array}$ & $\begin{array}{l}-0.0026 \\
(0.0079)\end{array}$ & $\begin{array}{l}-0.0096 \\
(0.0117)\end{array}$ \\
\hline Restaurant FE & $x$ & $x$ & $x$ & $x$ & $x$ & $x$ & $x$ & $x$ & $x$ \\
\hline Calendar FE & $x$ & $x$ & $x$ & $x$ & $x$ & $x$ & $x$ & $x$ & $x$ \\
\hline $\begin{array}{l}\text { Time-varying county } \\
\text { characteristics }\end{array}$ & $x$ & $x$ & $x$ & $x$ & $x$ & $x$ & $x$ & $x$ & $x$ \\
\hline City-specific time trend & & $x$ & & & $x$ & & & $x$ & \\
\hline County-year FE & & & $x$ & & & $x$ & & & $x$ \\
\hline
\end{tabular}

Each cell represents a different regression. Regressions are weighted by the number of restaurants at the city level.

Standard errors are clustered at the city level

Gap is a measure of the proportional increase of the city minimum wage over the state mandate

Number of observations $=8,134$

Calendar fixed effects = dummies for season and

year 
Table 8. The impact of the minimum wage on survival rates

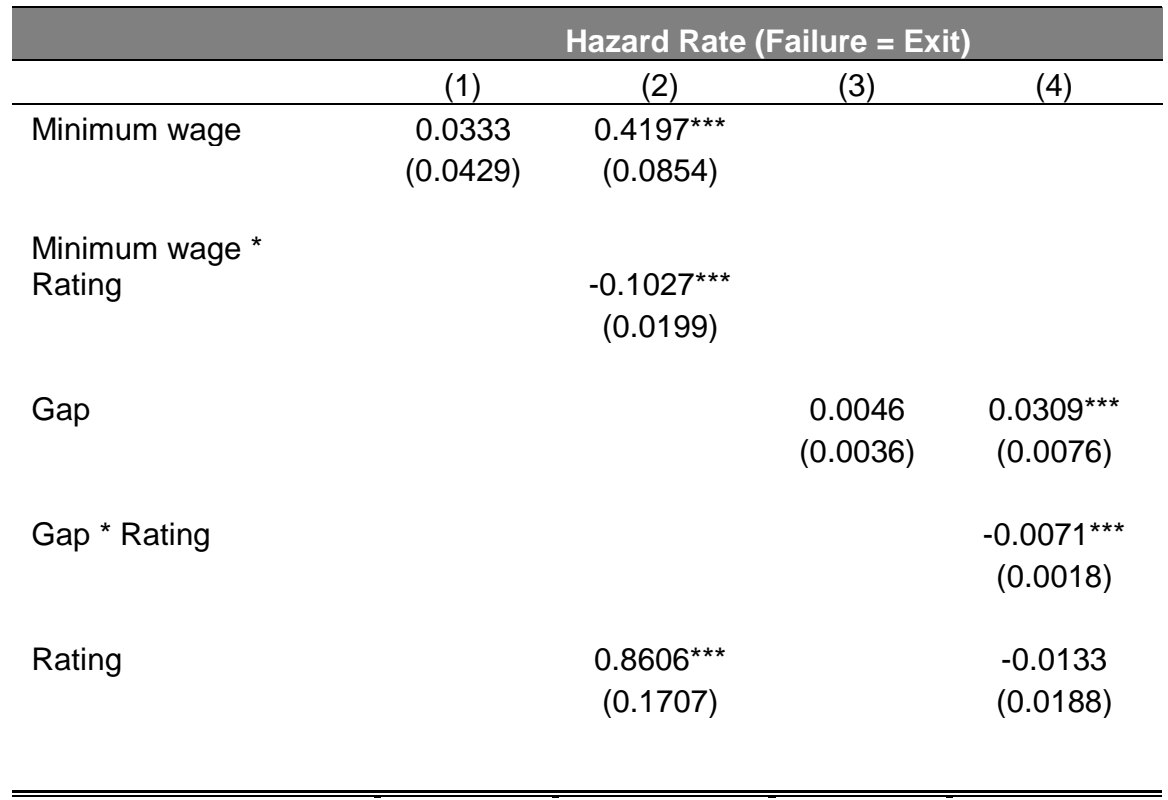

Standard errors are clustered at the city level. Coefficients are reported.

Gap is a measure of the proportional increase of the city minimum wage over the state mandate

Number of observations $=18,631$

The survival model includes controls for the total number of ratings at exit or end of panel, time-varying county level characteristics, price category of the restaurant, and dummies for year of entry. 